\title{
Effects of Dietary Fiber Extracted from Citrus (Citrus unshiu S. Marcoy) Peel on Physicochemical Properties of a Chicken Emulsion in Model Systems
}

\author{
Yun-Sang Choi ${ }^{1}$, Hyun-Wook Kim, Ko-Eun Hwang, Dong-Heon Song, \\ Hack-Youn Kim², Mi-Ai Lee ${ }^{3}$, Yohan Yoon ${ }^{4}$, and Cheon-Jei Kim* \\ Department of Food Science and Biotechnology of Animal Resources, Konkuk University, Seoul 143-701, Korea \\ ${ }^{1}$ Food and Biological Resources Examination Division, Korean Intellectual Property Office, Daejeon 302-701, Korea \\ ${ }^{2}$ College of Industrial Science Department of Animal Science, Kongju National University, Chungnam 340-702, Korea \\ ${ }^{3}$ World Institute of Kimchi, An Annex of Korea Food Research Institute, Gyounggi-do, 463-746, Korea \\ ${ }^{4}$ Department of Food and Nutrition, Sookmyung Women's University, Seoul 140-742, Korea
}

\begin{abstract}
s
Citrus (Citrus unshiu S. Marcoy) industry by-products were used as a source of dietary fiber, and the effects of dietary fiber extracted from citrus peel on the proximate composition, $\mathrm{pH}$, color, protein solubility, cooking loss, emulsion stability, and apparent viscosity of a chicken emulsion in model systems were examined. Chicken emulsions were prepared by adding citrus peel fiber at four different concentrations $(1,2,3$, and 4\%). The apparent viscosity, redness, and yellowness of the chicken emulsion with citrus peel fiber were higher than those of the control $(p<0.05)$. The lightness values of the chicken emulsions were lower in treatments containing citrus peel fiber $(p<0.05)$. Furthermore, moisture content, cooking loss, and emulsion stability of the chicken emulsion with $1-2 \%$ citrus peel fiber were higher than those of other treatments $(p<0.05)$. Fat content was lower in the treatments with added citrus peel fiber than that in the control $(p<0.05)$. Chicken emulsions with added citrus peel fiber had improved quality characteristics, and the best results were obtained for the chicken emulsion with $2 \%$ added citrus peel fiber.
\end{abstract}

Key words: citrus peel fiber, chicken emulsion, model systems, dietary fiber, emulsion stability

\section{Introduction}

Citrus fruit is a major product of Jeju island in Korea, and many varieties are cultivated. Thus, the citrus industry produces a significant quantity of peel as a by-product. If the peels are not processed, they become waste and a possible source of environmental pollution (Wang et al., 2008; Yang et al., 2008). Citrus peel is a good source of pectin and dietary fiber and has various bioactive components, including vitamins, minerals, flavonoids, coumarin, carotenoids, synephrine, terpenoids, and limonoids required for human health (Kang et al., 2006; Kim et al., 2011). Citrus peel also has high nutritive value and contributes to lower blood cholesterol, decrease cancer risk, protect against coronary heart disease, improve glucose tolerance and insulin response, and reduce hyperlipidemia

*Corresponding author: Cheon-Jei Kim, Department of Food Science and Biotechnology of Animal Resources, Konkuk University, Seoul 143-701, Korea. Tel: 82-2-450-3684, Fax: 82-2-444-6695, E-mail: kimcj@konkuk.ac.kr and hypertension (Fernández-Ginés et al., 2004; Kurita et al., 2008; Viuda-Martos et al., 2010). Thus, recent approaches to develop products from citrus peel have placed an emphasis on the production of potentially important secondary metabolites such as recovering dietary fiber (Kim and Song, 2010; Kurita et al., 2008; Wang et al., 2008; Viuda-Martos et al., 2010).

Nutritionists recommend a dietary fiber intake of $35 \mathrm{~g}$ per person per day, but intake in many industrialized countries is currently estimated to be $<25$ g per person per day (Choi et al., 2010; Vidua-Martos et al., 2010). Therefore, increasing the amount of dietary fiber in the diet without changing eating habits is particularly difficult. In recent years, dietary fiber has been studied regarding its potential use for developing functional foods, including meat products, fish products, breakfast cereals, bakery products, and dairy products (Sánchez et al., 2007; Vergara-Valencia et al., 2007). Dietary fiber is regularly incorporated into foods for its nutritional, functional, and technological properties (Choi et al., 2010; 
Grigelmo-Miguel and Martin-Belloso, 1999). Dietary fiber generally improves the stability, water holding capacity, swelling capacity, cooking yield, and textural properties of emulsions due to its water and fat binding properties and its ability to improve viscosity (Choi et al., 2009; Choi et al., 2010; Lee et al., 2008; Sarýçcoban et al., 2008; Shand, 2000; Wong and Cheung, 2000). Sarýçoban et al. (2008) reported that dietary fiber is not only desirable for their nutritional properties but also for functional and technological properties such as improving cooking yield, reducing formulation cost, and enhancing texture in food products. Furthermore, various types of dietary fiber have been used alone or combined with other ingredients to prepare meat-product formulations such as emulsion sausage, meat patties, restructured jerky, nuggets, and fermented sausage (Ajila et al., 2008; Choi et al., 2008; Eim et al., 2008; Turhan et al., 2005; Wong and Cheung, 2000; Yilmaz, 2004). Additionally, many studies have evaluated various sources of natural dietary fiber (Ajila et al., 2008; Choi et al., 2008; Eim et al., 2008; Turhan et al., 2005; Wong and Cheung, 2000; Yilmaz, 2004), but a limited number of studies have reported on dietary fiber from citrus peel added to chicken meat products.

Therefore, the aim of this study was to investigate the effects of adding different amounts of dietary fiber extracted from citrus peel on proximate composition, $\mathrm{pH}$, color, protein solubility, cooking loss, emulsion stability, and apparent viscosity of a chicken emulsion in model systems.

\section{Materials and Methods}

\section{Preparation and processing of the citrus peel dietary fiber extract}

Organic citrus (Citrus unshiu S. Marcoy) peel was obtained from local grocery store (Seoul, Korea), and insecticides residuals were washed out three times with four volumes of water, and then the residue was washed three times with three volumes of heated water (Lee, 1999). The residue was dried $\left(50^{\circ} \mathrm{C}\right)$ overnight in an air oven, cooled, and then washed with $99.9 \%$ ethanol (preheated to $60^{\circ} \mathrm{C}$ ), followed by filtration. The residue was dried $\left(50^{\circ} \mathrm{C}\right)$ overnight in an air oven and then cooled. The residue was ground using a blender (KA-2610, Jworld Tech, Korea) for $1 \mathrm{~min}$ and passed through a 35 mesh sieve (particle size, $<0.5 \mathrm{~mm}$ ). The citrus peel fiber (dietary fiber: $74.67 \pm 3.69 \%$, moisture content: $6.48 \pm 0.71 \%$, protein content: $3.60 \pm 0.36 \%$, fat content: $2.79 \pm 0.12 \%$, ash content: $2.39 \pm 0.10 \%$ ) was then placed in polyethyl- ene bags, vacuum packaged using a vacuum packaging system (FJ-500XL, Fujee Tech, Korea), and stored at $-4^{\circ} \mathrm{C}$ until used for product manufacture. The lightness, redness, and yellowness values of the citrus peel fiber were $71.95 \pm 3.14,3.44 \pm 1.14$, and $65.01 \pm 1.74$, respectively, and the $\mathrm{pH}$ was $5.06 \pm 0.03$.

\section{Preparation and processing of the chicken emul- sion in model system}

Fresh chicken breast meat (broilers, Muscularis pectoralis major, $5 \mathrm{wk}$ of age, approximately 1.5-2.0 kg live weight, moisture content: $74.95 \pm 0.97 \%$, protein content: $22.58 \pm 0.43 \%$, fat content: $0.09 \pm 0.12 \%$, ash content: 1.31 $\pm 0.09 \%$ ) and pork back fat (moisture content: $12.61 \%$, fat content: $85.64 \%$ ) were purchased from a local processor. The chicken breast meat and pork back fat were first ground through an 8-mm plate and then ground through a 3 -mm plate. The ground tissue was placed in polyethylene bags, vacuum-packaged using a vacuum packaging system, and stored at $0^{\circ} \mathrm{C}$ until used for product manufacture (within $1 \mathrm{wk})$. Suitable amounts of muscle $(12.5 \mathrm{~kg}$ ) and fat $(8 \mathrm{~kg})$ were tempered at $4^{\circ} \mathrm{C}$ for $24 \mathrm{~h}$ prior to preparing the meat batter. Each batch of samples consisted of five different meat emulsion in model systems with different percentages of added dietary fiber extracted from citrus peel $(0,1,2,3$, and $4 \%)$. Thus, five different chicken emulsions in model systems were formulated (Table 1) as follows: raw meat was homogenized and ground for 1 min in a silent cutter (Cutter Nr-963009, Germany). $\mathrm{NaCl}$ $(1.5 \%)$ and sodium tripolyphosphate $(0.2 \%)$ were added to the chicken breast meat, which had been previously dissolved in water and chilled $\left(2^{\circ} \mathrm{C}\right)$, and then mixed for $1 \mathrm{~min}$. Citrus peel fiber was added to the chicken meat

Table 1. Chicken meat emulsion formulations with various levels of citrus peel fiber (units: $\mathrm{g} / 100 \mathrm{~g}$ )

\begin{tabular}{lccccc}
\hline \hline \multirow{2}{*}{ Ingredients } & \multicolumn{5}{c}{ Treatments $^{1)}$} \\
\cline { 2 - 6 } & Control & $\mathrm{T} 1$ & $\mathrm{~T} 2$ & $\mathrm{~T} 3$ & $\mathrm{~T} 4$ \\
\hline Chicken breast meat & 50 & 49 & 48 & 47 & 46 \\
Back fat & 30 & 30 & 30 & 30 & 30 \\
Ice & 20 & 20 & 20 & 20 & 20 \\
Citrus peel fiber & - & 1.0 & 2.0 & 3.0 & 4.0 \\
\hline Total & 100 & 100 & 100 & 100 & 100 \\
\hline Salt & 1.5 & 1.5 & 1.5 & 1.5 & 1.5 \\
Sodium tripolyphosphate & 0.15 & 0.15 & 0.15 & 0.15 & 0.15 \\
\hline
\end{tabular}

${ }^{1)}$ Control, chicken meat emulsion system without citrus peel fiber; T1, chicken meat emulsion system with $1 \%$ citrus peel fiber; T2, chicken meat emulsion system with $2 \%$ citrus peel fiber; T3, chicken meat emulsion system with $3 \%$ citrus peel fiber; T4, chicken meat emulsion system with $4 \%$ citrus peel fiber 
emulsions in model systems and they were homogenized for 6 min. A temperature probe (Kane-May, KM330, UK) was used to monitor temperature in the emulsions and was maintained $<10^{\circ} \mathrm{C}$ during batter preparation. Five $\mathrm{kg}$ batches of each chicken emulsion in model systems were prepared in this manner. All analyses were carried out in triplicate for each formulation.

\section{Proximate composition}

The compositional properties of the chicken emulsions in model systems were determined using AOAC methods (2007). Moisture content was determined by weight loss after $12 \mathrm{~h}$ of drying at $105^{\circ} \mathrm{C}$ in a drying oven (SW-90D, Sang Woo Scientific, Korea). Fat content was determined by the Soxhlet method with a solvent extraction system (Soxtec Avanti 2050 Auto System, Foss Tecator AB, Sweden), and protein was determined by the Kjeldahl method with an automatic Kjeldahl nitrogen analyzer (Kjeltec 2300 Analyzer Unit, Foss Tecator AB). Ash was determined according to AOAC method 923.03.

\section{Dietary fiber measurements}

Duplicate fat free dry was analyzed for total dietary fiber of citrus peel fiber using the method of Lee et al. (1992). This method includes enzymatic hydrolysis with $\alpha$-amylase (heat-stable, A3306-10ML, Sigma, St. Louis, USA), protease (protease from Aspergillus oryzae, P6110250ML, Sigma), and amyloglucosidase (amyloglucosidase from Aspergillus niger, solution, A9913-10ML, Sigma), using MES-TRIS buffer. Triplicates of approximately $1 \mathrm{~g}$ samples were suspended in $40 \mathrm{~mL}$ MES-TRIS buffer and submitted to an enzymatic hydrolysis sequence: $50 \mathrm{~mL}$ of thermo resistant á-amylase, a water bath for 35 $\mathrm{min}$, and $100 \mu \mathrm{L}$ of protease in a water bath at $60^{\circ} \mathrm{C}$ for 30 min. Subsequently, the $\mathrm{pH}$ was corrected to 4.0-4.7, and $300 \mu \mathrm{L}$ amyloglucosidase was added to the mixture in the water bath at $60^{\circ} \mathrm{C}$ for $30 \mathrm{~min}$. Finally, fiber was precipitated with $95 \%$ ethanol at $60^{\circ} \mathrm{C}$. The sample was filtered into fritted glass crucibles using glass wool as the filtration agent. Crucibles containing the residue were dried in a $105^{\circ} \mathrm{C}$ dry oven, cooled in a dessicator, and weighed.

\section{pH}

The $\mathrm{pH}$ values of the chicken emulsions in model systems were measured in a homogenate prepared with $5 \mathrm{~g}$ of sample and distilled water $(45 \mathrm{~mL})$ using a $\mathrm{pH}$ meter (Model 340, Mettler-Toledo GmbH, Switzerland). All determinations were performed in triplicate.

\section{Color evaluation}

The color of each chicken emulsion in model systems was determined using a colorimeter (Minolta Chroma meter CR-210, Minolta Co., Japan; illuminate C, calibrated with a white plate, $\left.L^{*}=+97.83, a^{*}=-0.43, b^{*}=+1.98\right)$. Six measurements from each of five replicates were taken. Lightness (CIE L ${ }^{*}$-value), redness (CIE a ${ }^{*}$-value), and yellowness (CIE $b^{*}$-value) values were recorded.

\section{Protein solubility}

Protein solubility was utilized as an indicator of protein denaturation (Joo et al., 1999). Sarcoplasmic protein solubility was determined by dissolving $2 \mathrm{~g}$ of meat batter in $20 \mathrm{~mL}$ of ice-cold $25 \mathrm{mM}$ potassium phosphate buffer (pH 7.2). The chicken emulsion samples and buffer were homogenized (Model AM-7, Nihonseiki Kaisha Ltd., Japan) on ice set at $1,500 \times \mathrm{g}$ and were left to stand on a shaker at $4^{\circ} \mathrm{C}$ overnight. The mixtures were then centrifuged at $1,500 \times \mathrm{g}$ for $20 \mathrm{~min}$, and the protein concentrations of the supernatants were determined using the Biuret method (Gornall et al., 1949). Total protein solubility was determined by homogenizing $2 \mathrm{~g}$ of muscle powder in $20 \mathrm{~mL}$ of ice-cold $1.1 \mathrm{M}$ potassium iodide in a $100 \mathrm{M}$ phosphate buffer ( $\mathrm{pH}$ 7.2). The procedures for homogenization, shaking, centrifugation, and protein deter-mination were the same as those described above. Myofibrillar protein solubility was obtained by determining the difference between the total and sarcoplasmic protein solubilities.

\section{Cooking loss}

Cooking loss of chicken emulsion was determined by calculating the weight differences before and after cooking as follows:

Cooking loss (\%)

$=[$ (weight of raw chicken emulsion

- weight of cooked chicken emulsion)/

weight of raw chicken emulsion] $\times 100$

\section{Emulsion stability}

The chicken emulsions in model systems were analyzed for emulsion stability using the method of Bloukas and Honikel (1992) with the following modifications. Pre-weighed graduated glass tubes $15 \mathrm{~mL}-0.2 \mathrm{~mL}$ graduated units (Pyrex Chojalab Co., Korea) were filled with batter in the middle of a 15 mesh sieve. The glass tubes were covered and heated for $30 \mathrm{~min}$ in a boiling water bath to a core temperature of $75 \pm 1^{\circ} \mathrm{C}$. After cooling to $4 \pm 1^{\circ} \mathrm{C}$ to facilitate fat and water layer separation, the total 
expressible fluid and fat separated in the bottom of each graduated glass tube was measured and calculated (Choi et al., 2009).

Total expressible fluid separation $(\mathrm{mL} / \mathrm{g})$

$=[($ the water layer $(\mathrm{mL})+$ the fat layer $(\mathrm{mL}))$

/weight of raw meat batter $(\mathrm{g})] \times 100$

Fat separation $(\mathrm{mL} / \mathrm{g})$

$=[$ the fat layer $(\mathrm{mL}) /$ weight of raw meat batter $(\mathrm{g})]$ $\times 100$

\section{Apparent viscosity}

Chicken emulsion in model systems viscosity was measured in triplicate with a rotational viscometer (HAKKE Viscotester 550, Thermo Electron Corporation, Germany) set at $10 \mathrm{rpm}$. A standard cylinder sensor (SV-2) was positioned in a $25 \mathrm{~mL}$ metal cup filled with batter and allowed to rotate under a constant share rate for $30 \mathrm{~s}$ before each reading was taken. Apparent viscosity values were obtained in centipoises. The temperature of each sample at the time $\left(18 \pm 1^{\circ} \mathrm{C}\right)$ of viscosity testing was also recorded (Shand, 2000).

\section{Statistical analysis}

All tests were conducted at least three times for each experimental condition, and mean values are reported. An analysis of variance was performed on all variables using the general linear model procedure of the SAS statistical package (2008). Duncan's multiple range test $(p<0.05)$ was used to determine differences among treatments.

\section{Results and Discussion}

\section{Proximate composition of the chicken emulsions in model systems}

The proximate compositions of the chicken emulsions in model systems formulated with different levels of citrus peel fiber are presented in Table 2. Moisture content was affected by the citrus peel fiber concentration. Among the control and all citrus peel fiber treatments, the 1 and $2 \%$ citrus peel fiber treatments had higher moisture concentration $(p<0.05)$. This increase in moisture content could have been due to water released from the meat matrix that was retained by the citrus peel fiber during the emulsion process (Lee et al., 2008). These results agree with those reported by Fernández-Ginés et al. (2004), in which moisture content increased significantly with the addition of dietary fiber to meat products from lemon albedo, due to the pectin in the lemon albedo, which may constitute up to $25 \%$ of lemon albedo. Protein content was lower in treatments with 3 and $4 \%$ added citrus peel fiber than that in the control and treatments with 1 and $2 \%$ added citrus peel fiber samples $(p<0.05)$, because these meat batters were formulated initially with more citrus peel fiber and less chicken breast (Table 1). Fat content was lower in the treatments with added citrus peel fiber than that in the control samples $(p<0.05)$. Fat content may have been affected by the added citrus peel fiber, whose moisture content increased. These results agree with those reported by Choi et al. (2012), in which fat content showed similar results to reduced-fat patties with added dietary fiber from Laminaria japonica. Ash content increased when citrus peel fiber was added depending on the citrus peel fiber concentration $(p<0.05)$, as the ash content of citrus peel fiber was $2.39 \%$. Similar results were reported by Choi et al. (2010) for meat emulsion systems with added rice bran fiber. These results indicate that ash content significantly increased with the addition of rice bran fiber to the meat systems.

\section{pH and color of the chicken emulsions in model systems}

The $\mathrm{pH}$, lightness (CIE $\mathrm{L}^{*}$-value), redness (CIE a*value), and yellowness ( $\mathrm{CIE} \mathrm{b}^{*}$-value) values of the raw and cooked chicken emulsions in model systems are pre-

Table 2. Proximate composition (\%) of chicken emulsion formulated with various levels of citrus peel fiber

\begin{tabular}{ccccc}
\hline \hline Treatments $^{1)}$ & Moisture & Protein & Fat & Ash \\
\hline Control $^{\text {T1 }}$ & $59.63 \pm 0.98^{\mathrm{B}}$ & $12.67 \pm 0.18^{\mathrm{A}}$ & $23.92 \pm 0.48^{\mathrm{A}}$ & $2.06 \pm 0.04^{\mathrm{B}}$ \\
$\mathrm{T} 2$ & $61.03 \pm 0.80^{\mathrm{A}}$ & $12.38 \pm 0.15^{\mathrm{A}}$ & $21.34 \pm 1.48^{\mathrm{B}}$ & $2.07 \pm 0.04^{\mathrm{B}}$ \\
T3 & $61.96 \pm 0.34^{\mathrm{A}}$ & $12.40 \pm 0.16^{\mathrm{A}}$ & $22.27 \pm 0.75^{\mathrm{AB}}$ & $2.10 \pm 0.12^{\mathrm{AB}}$ \\
T4 & $60.12 \pm 0.43^{\mathrm{AB}}$ & $11.96 \pm 0.21^{\mathrm{B}}$ & $22.31 \pm 0.16^{\mathrm{AB}}$ & $2.20 \pm 0.07^{\mathrm{A}}$ \\
\hline
\end{tabular}

All values are mean $\pm \mathrm{SD}$ of three replicates.

${ }^{\mathrm{A}, \mathrm{B}}$ Means within a column with different letters are significantly different $(p<0.05)$.

${ }^{1)}$ Control, chicken meat emulsion system without citrus peel fiber; T1, chicken meat emulsion system with $1 \%$ citrus peel fiber; T2, chicken meat emulsion system with $2 \%$ citrus peel fiber; T3, chicken meat emulsion system with $3 \%$ citrus peel fiber; T4, chicken meat emulsion system with $4 \%$ citrus peel fiber 
sented in Table 3. Increasing citrus peel fiber levels significantly decreased $\mathrm{pH}(p<0.05)$, which may have occurred because the $\mathrm{pH}$ of the citrus peel fiber was 5.06. Kim and Song (2010) reported that adding citrus powder decreases the $\mathrm{pH}$ of food due to the effects of organic acids such as citric acid, tartaric acid, and ascorbic acid. Lee et al. (2008) reported that the $\mathrm{pH}$ of emulsion-type sausage with added citron peel powder decreased with a decrease in added citron peel powder, because the citron peel power contained an acidic ingredient. However, Fernández-Ginés et al. (2004) indicated that the pH of bologna sausages did not differ between control and treatments containing lemon albedo. Generally, the $\mathrm{pH}$ of meat products with added dietary fiber is affected depending on the acidity and alkalinity of the natural source of dietary fiber.

The differences in lightness, redness, and yellowness values of chicken emulsions in model systems with added citrus peel fiber were statistically significant compared to those in the control (Table 3). The lightness values of the chicken emulsions were lower in treatments containing citrus peel fiber compared to those of the control $(p<0.05)$. Increasing the proportion of citrus peel fiber significantly decreased the lightness values $(p<0.05)$, due to the added citrus peel fiber. The chicken emulsions in model systems containing increasing citrus peel fiber concentrations resulted in increased redness and yellowness $(p<0.05)$. Similar trends in lightness were observed in a study by Fernández-Ginés et al. (2004), when dietary fiber from lemon albedo was added to bologna sausage. Kim and Song (2010) showed that adding citrus mandarin powder to gamgyul-unjeulmi resulted in a lower lightness value than that of the control. These results indicate that the redness and yellowness of food increase with increasing added citrus powder content due to the effect of the citrus powder color. These results agree with those reported by Calvo et al. (2008) who noted that adding tomato peel to fermented sausage increases redness due to lycopene and carotenoid oxidation. Lee et al. (2008) reported that the yellowness of emulsion sausage increases significantly with increasing citron peel fiber content, because citron peel fiber increases yellowness. Generally, color changes in meat products occur by adding different sources of natural dietary fiber from various sources (Choi et al., 2009; Eim et al., 2010; Fernández-Ginés et al., 2004; JiménezColmenero et al., 2003; Lee et al., 2008; Yang et al., 2007).

\section{Protein solubility of the chicken emulsions in model systems}

The protein solubility of sarcoplasmic, myofibrillar, and total proteins in the chicken emulsions in model systems formulated with different levels of citrus peel fiber are shown in Fig. 1. The sarcoplasmic, myofibrillar, and total protein solubilities were not significantly different between the control and the citrus peel fiber treatments. These results are in agreement with those of Choi et al. (2010), who found that meat batter with added dietary fiber does not result in significantly different protein solubilities between the control and treatments with added dietary fiber. In general, protein solubility of fresh meat is mainly affected by post-mortem glycolysis and water holding capacity of meat, but salt and phosphate levels in the sample are the major factor influencing protein solubility in meat products. Choi et al. (2010) reported that protein solubility profiles are an effective indicator of the degree of protein denaturation during meat processing, particularly that the protein solubility of meat products may affect their textural qualities (Astiasaran et al., 1990). Furthermore, the sarcoplasmic and myofibrillar protein solubilities in different quality meat products are produced under carefully controlled conditions (Sayre and Briskey, 1963). High total protein and sarcoplasmic protein solubilities are important for high quality processed

Table 3. Effect of various levels of citrus peel fiber on $\mathrm{pH}$ and color (CIE $L^{*}-, a^{*}$-, and $b^{*}$-values) in chicken emulsions

\begin{tabular}{ccccc}
\hline \hline Treatments $^{1)}$ & $\mathrm{pH}$ & CIE $L^{*}$-value & CIE $a^{*}$-value & CIE $b^{*}$-value \\
\hline Control & $6.58 \pm 0.02^{\mathrm{A}}$ & $84.57 \pm 0.99^{\mathrm{A}}$ & $2.69 \pm 0.17^{\mathrm{A}}$ & $11.03 \pm 0.40^{\mathrm{E}}$ \\
T1 & $6.45 \pm 0.03^{\mathrm{B}}$ & $83.85 \pm 1.69^{\mathrm{AB}}$ & $0.31 \pm 0.18^{\mathrm{E}}$ & $27.10 \pm 1.14^{\mathrm{D}}$ \\
T2 & $6.34 \pm 0.02^{\mathrm{C}}$ & $82.95 \pm 1.57^{\mathrm{B}}$ & $0.47 \pm 0.14^{\mathrm{D}}$ & $34.73 \pm 0.78^{\mathrm{C}}$ \\
T3 & $6.22 \pm 0.08^{\mathrm{D}}$ & $81.22 \pm 1.50^{\mathrm{B}}$ & $0.66 \pm 0.48^{\mathrm{C}}$ & $39.70 \pm 1.36^{\mathrm{B}}$ \\
T4 & $6.10 \pm 0.04^{\mathrm{E}}$ & $79.29 \pm 2.97^{\mathrm{C}}$ & $0.85 \pm 0.28^{\mathrm{B}}$ & $43.35 \pm 1.08^{\mathrm{A}}$ \\
\hline
\end{tabular}

All values are mean $\pm \mathrm{SD}$ of three replicates.

A-F Means within a column with different letters are significantly different $(p<0.05)$.

${ }^{1)}$ Control, chicken meat emulsion system without citrus peel fiber; T1, chicken meat emulsion system with $1 \%$ citrus peel fiber; T2, chicken meat emulsion system with $2 \%$ citrus peel fiber; T3, chicken meat emulsion system with $3 \%$ citrus peel fiber; T4, chicken meat emulsion system with $4 \%$ citrus peel fiber 


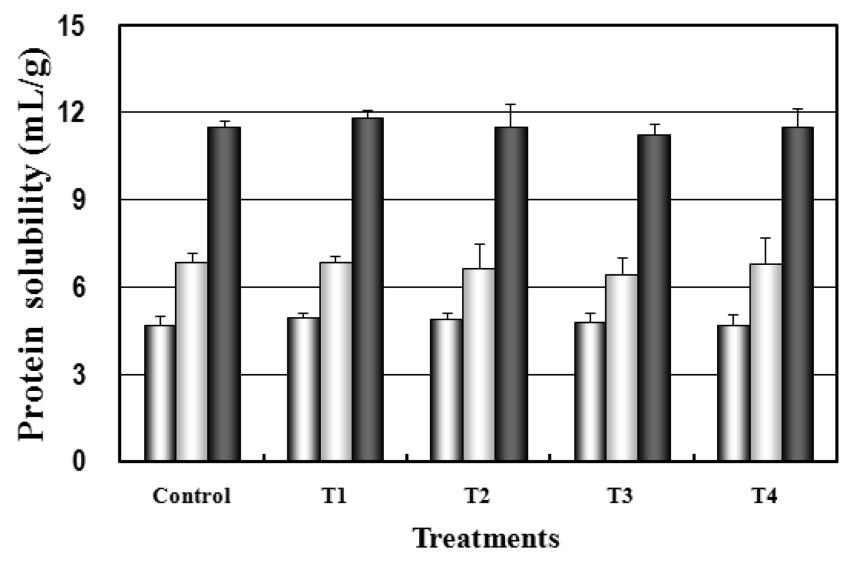

Fig. 1. Effect of protein solubility on chicken emulsion systems containing various citrus peel fiber levels. Control, chicken meat emulsion system without citrus peel fiber; $\mathrm{T} 1$, chicken meat emulsion system with $1 \%$ citrus peel fiber; T2, chicken meat emulsion system with $2 \%$ citrus peel fiber; T3, chicken meat emulsion system with $3 \%$ citrus peel fiber; $\mathrm{T} 4$, chicken meat emulsion system with $4 \%$ citrus peel fiber, $\square$, sarcoplasmic protein; $\square$, myofibrillar protein; $\square$, total protein. Data were no significant difference among samples means $(p>0.05)$. Results are means of at least three experiments.

meat products, because they are an excellent indicator of the functional properties of meat (Young et al., 2005).

\section{Cooking loss and emulsion stability of the chicken emulsions in model systems}

Table 4 shows the cooking loss from the chicken emulsions in model systems formulated with various levels of citrus peel fiber. The cooking loss from the chicken emulsions in model systems with $2 \%$ added citrus peel fiber was the lowest at $5.04 \%$. These results are in agreement with a study indicating that cooking loss of patties is affected by the amount of added dietary fiber (Choi et al., 2012). Choi et al. (2009) noted that cooking loss decreased significantly with the addition of $1-3 \%$ rice bran fiber to meat emulsion systems, but a $4 \%$ rice bran fiber treatment did not significantly differ compared to that of the control. For this reason, added too much dietary fiber undermines the water holding capacity and water binding capacity in meat products. Additionally, Lee et al. (2008) noted that the reduction in cooking loss with increasing levels of dietary fiber is attributed to reduced cooking loss of the sausage. Sánchez-Zapata et al. (2010) showed that meat products with added tiger nut fiber have less cooking loss than that of the control. In fact, this was attributed to high moisture and fat cooking loss. Thus, several researchers have reported that dietary fiber decreases cooking loss by improving moisture and
Table 4. Effect of various levels of citrus peel fiber on cooking loss and emulsion stability in chicken emulsions

\begin{tabular}{|c|c|c|c|}
\hline \multirow[b]{2}{*}{ Treatments ${ }^{1)}$} & \multirow{2}{*}{$\begin{array}{c}\text { Cooking } \\
\text { loss } \\
(\%)\end{array}$} & \multicolumn{2}{|c|}{ Emulsion stability } \\
\hline & & $\begin{array}{l}\text { Total expressible fluid } \\
\text { separation }(\mathrm{mL} / \mathrm{g})\end{array}$ & $\begin{array}{c}\text { Fat separation } \\
(\mathrm{mL} / \mathrm{g})\end{array}$ \\
\hline Control & $8.52 \pm 0.24^{\mathrm{A}}$ & $6.47 \pm 0.53^{\mathrm{A}}$ & $1.46 \pm 0.32^{\mathrm{A}}$ \\
\hline $\mathrm{T} 1$ & $6.13 \pm 0.18^{\mathrm{C}}$ & $2.41 \pm 0.45^{\mathrm{D}}$ & $0.97 \pm 0.32^{\mathrm{C}}$ \\
\hline $\mathrm{T} 2$ & $5.04 \pm 0.51^{\mathrm{D}}$ & $2.94 \pm 0.39^{\mathrm{D}}$ & $0.99 \pm 0.41^{\mathrm{C}}$ \\
\hline $\mathrm{T} 3$ & $6.49 \pm 0.82^{\mathrm{BC}}$ & $3.95 \pm 0.41^{\mathrm{C}}$ & $1.11 \pm 0.23^{\mathrm{B}}$ \\
\hline T4 & $8.17 \pm 0.90^{\mathrm{AB}}$ & $5.33 \pm 0.80^{\mathrm{B}}$ & $1.18 \pm 0.24^{\mathrm{B}}$ \\
\hline
\end{tabular}

All values are mean \pm SD of three replicates

${ }^{\mathrm{A}-\mathrm{F}}$ Means within a column with different letters are significantly different $(p<0.05)$.

${ }^{1)}$ Control, chicken meat emulsion system without citrus peel fiber; $\mathrm{T} 1$, chicken meat emulsion system with $1 \%$ citrus peel fiber; $\mathrm{T} 2$, chicken meat emulsion system with $2 \%$ citrus peel fiber; T3, chicken meat emulsion system with $3 \%$ citrus peel fiber; T4, chicken meat emulsion system with $4 \%$ citrus peel fiber

fat binding capacities (Choi et al., 2012; Lee et al., 2008; Sánchez-Zapata et al., 2010). These findings indicate that adding citrus peel fiber results in desirable changes in the cooking characteristics of chicken emulsions in model systems and suggests that meat emulsion in model systems viscosity was possibly improved.

The chicken meat emulsion in model systems formulated with citrus peel fiber had significant differences in emulsion stability (Table 4). Total expressible fluid separation was lower in the chicken emulsion in model systems with added citrus peel fiber than that of the control $(p<0.05)$. Total expressible fluid was the lowest in the treatment containing $1 \%$ citrus peel fiber $(p<0.05)$. All treatments with added citrus peel fiber had significantly lower fat separation than that of the control $(p<0.05)$. According to Choi et al. (2010), meat emulsion batter with excess added dietary fiber impairs emulsion stability. These results indicate that meat batters with too much dietary fiber have weakened water and fat binding capacities. As a result, adding $1 \%$ citrus peel fiber to the chicken emulsion in model systems provided the greatest emulsion stability among all meat product treatments, which may have been due to the dietary fiber from citrus peel, which has high water holding and binding capacities (Choi et al., 2009; Choi et al., 2010; Lee et al., 2008). Similar results were observed by Wong and Cheung (2000), who reported that dietary fiber improves the quality characteristics of meat products by affecting the matrix structure of meat emulsion systems. These results showed that dietary fiber is a major contributor to water and fat binding in meat emulsion systems. The emulsion stability of meat emulsions is an index that roughly calculates the 
quality characteristics of the final meat product (Choi et al., 2009), and emulsion stability is an indicator of unseparated water and fat retained by meat emulsions (Sarıçoban et al., 2008). Thus, some researchers have suggested that the formation of a strong emulsion complex in a stable meat emulsion with no fluid loss is observed because the meat emulsions with dietary fiber had improved emulsion stability and rheological properties (Choi et al., 2010; Kim et al., 2010; Youssef and Barbut, 2009).

\section{Apparent viscosity of the chicken emulsions in model systems}

Fig. 2 shows the apparent viscosity values of the chicken emulsions in model systems formulated with various levels of citrus peel fiber. The treatments with added citrus peel fiber significantly affected the viscosity of the chicken emulsions in model systems. The control and all treatments with added citrus peel fiber revealed decreased apparent viscosity values with an increase in rotation time. The apparent viscosity values were higher in the chicken emulsions in model systems formulated with citrus peel fiber than those in the control, and the highest values were obtained in the $4 \%$ added citrus peel fiber samples $(p<0.05)$. Similar results were observed by Choi et al. (2009) in meat emulsions systems with added rice bran fiber, and by Aktas and Genccelep (2006) in frankfurters with added high-dietary fiber. According to Sar1çoban et al. (2008), various levels of dietary fiber from lemon albedo significantly affect the apparent viscosity of

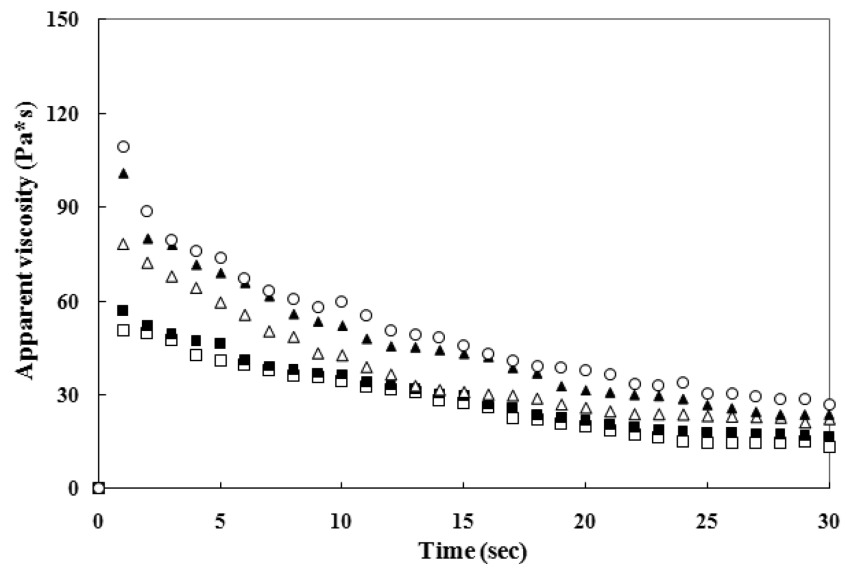

Fig. 2. Change in apparent viscosity of chicken meat emulsion systems containing various amounts of citrus peel fiber stirred for $30 \mathrm{sec}$. Control ( $\square$ ), chicken meat emulsion system without citrus peel fiber; T1 $(\square)$, chicken meat emulsion system with $1 \%$ citrus peel fiber; $\mathrm{T} 2(\triangle)$, chicken meat emulsion system with $2 \%$ citrus peel fiber; T3 $(\boldsymbol{\Delta})$, chicken meat emulsion system with $3 \%$ citrus peel fiber; T4 $(\bigcirc)$, chicken meat emulsion system with $4 \%$ citrus peel fiber. Results are means of at least three experiments. meat emulsion batters. They reported that the high apparent viscosity in meat emulsion systems is not easily broken. Some researchers have indicated that an increase in emulsion viscosity is related with an increase in emulsion stability due to the water binding capacity of a meat emulsion (Choi et al., 2009; Kim et al., 2010; Lee et al., 2008). Additionally, increasing apparent viscosity generally reduces cooking loss and emulsion stability. Thus, meat products with added dietary fiber have improved viscosity, which helps improve physicochemical properties such as cooking loss and emulsion stability.

\section{Conclusion}

The results of this study indicate that citrus peel fiber significantly affected the physicochemical characteristics of chicken emulsions in model systems. Thus, citrus peel fiber could be an excellent source of dietary fiber that can be used as a functional ingredient in chicken emulsions in model systems. The added dietary fiber extracted from citrus peel positively affected cooking loss, emulsion stability, and apparent viscosity. The best results were obtained with chicken emulsions in model systems containing $2 \%$ dietary fiber extracted from citrus peel.

\section{Acknowledgements}

This research was supported (608001-05-2-SB310) by the Rural Development Administration (Republic of Korea). The authors were also partially supported by the Brain Korean 21 (BK 21) Project from Ministry of Education and Human Resources Development (Republic of Korea).

\section{References}

1. Ajila, C. M., Leelavathi, K., and Prasada Rao, U. J. S. (2008) Improvement of dietary fiber content and antioxidant properties in soft dough biscuits with the incorporation of mango peel powder. J. Cereal Sci. 48, 319-326.

2. Aktas, N. and Genccelep, H. (2006) Effect of starch type and its modifications on physicochemical properties of bolognatype sausage produced with sheep tail fat. Meat Sci. 74, 404408.

3. AOAC (2007) Official methods of analysis. AOAC International. $18^{\text {th }}$ ed. $950.46,920.153,928.08,960.39$. Association of Official Analytical Chemists, Washington, DC.

4. Astiasaran, I., Villanueva, R., and Bello, J. (1990) Analysis of proteolysis and protein insolubility during the manufacture of some varieties of dry sausage. Meat Sci. 28, 111-117.

5. Bloukas, I. and Honikel, K. O. (1992) The influence of addi- 
tives on the oxidation of pork back fat and its effect on water and fat binding in finely comminuted batters. Meat Sci. 32, 31-43.

6. Calvo, M. M., Garcia, M. L., and Selgas, M. D. (2008) Dry fermented sausages enriched with lycopene from tomato peel. Meat Sci. 80, 167-172.

7. Choi, Y. S., Choi, J. H., Han, D. J., Kim, H. Y., Kim, H. W., Lee, M. A., Chung, H. J., and Kim, C. J. (2012) Effects of Laminaria japonica on the physico-chemical and sensory characteristics of reduced-fat pork patties. Meat Sci. 91, 1-7.

8. Choi, Y. S., Choi, J. H., Han, D. J., Kim, H. Y., Lee, M. A., Kim, H. W., Jeong, J. Y., and Kim, C. J. (2011) Effects of rice bran fiber on heat-induced gel prepared with pork salt-soluble meat proteins in model system. Meat Sci. 88, 59-66.

9. Choi, Y. S., Choi, J. H., Han, D. J., Kim, H. Y., Lee, M. A., Kim, H. W., and Kim, C. J. (2009) Characteristics of low-fat meat emulsion systems with pork fat replaced by vegetable oils and rice bran fiber. Meat Sci. 82, 266-271.

10. Choi, Y. S., Choi, J. H., Han, D. J., Kim, H. Y., Lee, M. A., Kim, H. W., Lee, J. W., Chung, H. J., and Kim, C. J. (2010) Optimization of replacing pork back fat with grape seed oil and rice bran fiber for reduced-fat meat emulsion systems. Meat Sci. 84, 212-218.

11. Choi, Y. S., Choi, J. H., Han, D. J., Kim, H. Y., Lee, M. A., Lee, E. S., Jeong, J. Y., Paik, H. D., and Kim, C. J. (2008) Effects of rice bran fiber on quality of low-fat Tteokgalbi. Food Sci. Biotechnol. 17, 959-964.

12. Eim, V. S., Simal, S., Rosselló, C., and Femenia, A. (2008) Effects of addition of carrot dietary fibre on the ripening process of a dry fermented sausage (sobrassada). Meat Sci. 80, 173-182.

13. Fernández-Ginés, J. M., Fernandez-López, J., Sayas-Barberá, E., Sendra, E., and Pérez-Álvarez, J. A. (2004) Lemon albedo as a new source of dietary fiber: Application to bologna sausages. Meat Sci. 67, 7-13.

14. Gornall, A. G., Bardawill, C. J., and David, M. M. (1949) Determination of serum proteins by means of the biuret reaction. J. Biol. Chem. 177, 751-766.

15. Grigelmo-Miguel, N. and Martin-Belloso, O. (1999) Comparison of dietary fibre from by-products of processing fruits and greens and from cereals. LWT-Food Sci. Technol. 32, 503-508.

16. Jiménez-Colmenero, F., Serrano, A., Ayo, J., Solas, M. T., Cofrades, S., and Carballo, J. (2003) Physicochemical and sensory characteristics of restructured beef steak with added walnuts. Meat Sci. 65, 1391-1397.

17. Joo, S. T., Kauffman, R. G., Kim, B. C., and Park, G. B. (1999) The relationship of sarcoplasmic and myofibrillar protein solubility to colour and water-holding capacity in porcine longissimus muscle. Meat Sci. 52, 291-297.

18. Kang, H. J., Chawla, S. P., Jo, C., Kwon, J. H., and Byun, N. W. (2006) Studies on the development of functional powder from citrus peel. Biores. Technol. 97, 614-620.

19. Kim, C. W. and Song, E. (2010) Qualtiy characteristics of Gamgyul-Injeulmi with citrus mandarin powder during storage. Korean J. Food Nutr. 23, 247-257.
20. Kim, H. Y., Lee, E. S., Jeong, J. Y., Choi, J. H., Choi, Y. S., Han, D. J., Lee, M. A., Kim, S. Y., and Kim, C. J. (2010) Effect of bamboo salt on the physicochemical properties of meat emulsion systems. Meat Sci. 86, 960-965.

21. Kim, N. Y., Yu, A. R., Min, J. Y., and Han, M. J. (2011) Fermentation characteristics of Ginpi wine with different levels of added Ginpi. Korean J. Food Culture 26, 178-183.

22. Kurita, S., Fujiwara, T., and Yamazaki, E. (2008) Characterization of the pectin extracted from citrus peel in the presence of citric acid. Carbohydr. Polymers 74, 725-730.

23. Lee, M. A., Han, D. J., Jeong, J. Y., Choi, J. H., Choi, Y. S., Kim, H. Y., Paik, H. D., and Kim, C. J. (2008) Effect of kimchi powder level and drying methods on quality characteristics of breakfast sausage. Meat Sci. 80, 708-714.

24. Lee, M. G. (1999) Computation of residue limit of organophosphorus pesticides in functional foods from citrus fruit peels. Korean J. Environ. Agric. 18, 349-354.

25. Lee, S. C., Prosky, L., and Devries, J. W. (1992) Determination of total, soluble, and insoluble dietary fiber in foods. Enzymatic-gravimetric method, MES-TRIS buffer: collaborative study. J. Assoc. Off. Anal. Chem. Int. 75, 395-416.

26. Sánchez-Zapata, E., Muñoz, C. M., Fuentes, E., FernándezLópez, J., Sendra, E., Sayas, E., Navarro, C., and PérezAlvarez, J. A. (2010) Effect of tiger nut fibre on quality characteristics of pork burger. Meat Sci. 85, 70-76.

27. Sarıçoban, C., Özalp, B., Yilmaz, M. T., Özen, G., Karakaya, M., and Akbulut, M. (2008) Characteristics of meat emulsion systems as influenced by different levels of lemon albedo. Meat Sci. 80, 599-606.

28. SAS (2008) SAS/STAT Software for PC. Release 9.2, SAS Institute Inc., Cary, NC, USA.

29. Sayre, R. N. and Briskey, E. J. (1963) Protein solubility as influenced by physiological conditions in the muscle. $J$. Food Sci. 28, 675-679.

30. Shand, P. J. (2000) Textural, water holding, and sensory properties of low-fat pork bologna with normail and waxy starch hull-less barley. J. Food Sci. 65, 101-107.

31. Turhan, S., Sagir, I., and Ustun, N. S. (2005) Utilization of hazelnut pellicle in low-fat beef burgers. Meat Sci. 71, 312316.

32. Vergara-Valencia, N., Granados-Pérez, E., Agama-Acevedo, E., Tovar, J., Ruales, J., and Bello-Pérez, L. A. (2007) Fibre concentrate from mango fruit: characterization, associated antioxidant capacity and application as a bakery product ingredient. LWT-Food Sci. Technol. 40, 722-729.

33. Viuda-Martos, M., Ruiz-Navajas, Y., Fernandez-Lopez, J., and Perez-Alvarez, J. A. (2010) Effect of adding citrus fibre washing water and rosemary essential oil on the quality characteristics of a bologna sausage. LWT-Food Sci. Technol. 43, 958-963.

34. Wang, Y. C., Chuang, Y. C., and Hsu, H. W. (2008) The flavonoid, carotenoid and pectin content in peels of citrus cultivated in Taiwan. Food Chem. 106, 277-284.

35. Wong, K. H. and Cheung, P. C. K. (2000) Nutritional evaluation of some subtropical red and green seaweeds. Proximate composition, amino acid profiles and some physic-chemical 
properties. Food Chem. 71, 475-482.

36. Yang, H. S., Choi, S. G., Jeon, J. T., Park, G. B., and Joo, S. T. (2007) Textural and sensory properties of low fat pork sausages with added hydrated oatmeal and tofu as texture-modifying agent. Meat Sci. 75, 283-289.

37. Yang, Y. T., Kim, M. S., Hyun, K. H., Kim, Y. C., and Koh, J. S. (2008) Chemical constituents and flavonoids in citrus pressed cake. Korean J. Food Preserv. 15, 94-98.

38. Yilmaz, I. (2004) Effects of rye bran addition on fatty acid composition and quality characteristics of low-fat meatballs.
Meat Sci. 67, 245-249.

39. Young, O. A., Zhang, S. X., Farouk, M. M., and Podmore, C. (2005) Effect of $\mathrm{pH}$ adjustment with phosphates on attributes and functionalities of normal and high $\mathrm{pH}$ beef. Meat Sci. 70, 133-139.

40. Youssef, M. K. and Barbut, S. (2009) Effects of protein level ad fat/oil on emulsion stability, texture, microstructure and color of meat batters. Meat Sci. 82, 228-233.

(Received 2012.6.22/Revised 2012.9.17/Accepted 2012.10.11) 